\title{
Gambaran Kecemasan Preoperatif Sectio Caesarea dengan Anestesi Spinal di RSIA Siti Hawa Padang
}

\author{
Rani IIma Imani ${ }^{1}$, M. Zulfadli Syahrul', Dedy Kurnia ${ }^{3}$ \\ ${ }^{1}$ Fakultas Kedokteran Universitas Andalas, Padang \\ ${ }^{2}$ Bagian Anestesi RSUP Dr. M. Djamil, Padang \\ ${ }^{3}$ Bagian Obgyn Fakultas Kedokteran Universitas Andalas, Padang
}

\section{A B S T R A C T}

\begin{abstract}
Latar Belakang. Kecemasan adalah respons terhadap suatu ancaman yang asalnya tidak diketahui, internal, samar-samar, atau konfliktual. Salah satu penyebab kecemasan tersering di dunia adalah pasien yang dinyatakan akan menjalani operasi.

Objektif. Penelitian ini bertujuan untuk memberikan gambaran kecemasan pasien preoperatif sectio caesarea dengan anestesi spinal di RSIA Siti Hawa Padang.
\end{abstract}

Metode. Penelitian ini merupakan penelitian deskriptif observasional dengan desain cross-sectional yang dilakukan pada bulan Juli - Agustus 2018. Pengumpulan data dengan cara melakukan wawancara langsung kepada delapan puluh tiga responden dengan menggunakan kuesioner The Amsterdam Preoperative Anxiety and Information Scale (APAIS). Populasi penelitian yaitu semua pasien yang akan melakukan operasi SC dengan anestesi spinal di RSIA Siti Hawa Padang periode Juli 2018 - Agustus 2018. Jumlah sampel penelitian sebanyak 83 orang sesuai dengan kriteria inklusi dan ekslusi.

Hasil. Hasil penelitian kecemasan berdasarkan kuesioner APAIS, sebagian besar tidak mengalami kecemasan preoperatif $(51,8 \%)$ dan lebih banyak pada tingkat kebutuhan informasi rendah (48,2\%). Kecemasan preoperatif terbanyak pada kelompok usia dua puluh sampai tiga puluh lima tahun (54\%), berdasarkan tingkat pendidikan lebih banyak pada lulusan perguruan tinggi (62,9\%), berdasarkan riwayat operasi lebih banyak pada pasien yang belum pernah menjalani operasi (63\%), dan berdasarkan sumber informasi lebih banyak pada pasien yang sudah mengetahui prosedur operasi $(53,3 \%)$.

Kesimpulan. Sebagian besar pasien tidak mengalami kecemasan preoperatif $(51,8 \%)$ dan untuk kebutuhan informasi lebih banyak pada tingkat kebutuhan informasi rendah $(48,2 \%)$.

Kata kunci: kecemasan, kecemasan preoperatif, sectio caesarea, anestesi spinal

Background. Anxiety is a response to a threat that comes nowhere, internally, indistinctly, or conflictual. One common cause of anxiety in the world is a patient that will experience an operation.

Objective. This study aimed to give the incidence of the anxiety of cesarean section pre-operative patients with spinal anesthesia at Siti Hawa's Mother and Child Hospital Padang.

Method. This study was observational-descriptive with a crosssectional design done from July until August 2018. Data were collected by direct interview with eighty-three respondents using The Amsterdam Preoperative Anxiety and Information Scale (APAIS) questionnaire. The population in this study were all the patients who want to do cesarean section surgery with spinal anesthesia at Siti Hawa's Mother and Child Hospital Padang. The number of research samples was 83 people according to inclusion and exclusion criteria. Result. This result of this study based on APAIS questionnaire was $(51,8 \%)$ patients do not feel anxiety and the most need for information was low (48,2\%). The highest frequency of preoperative anxiety were patients twenty to thirty-five years old (54\%), based on education levels (62,9\%) patients graduated from college, based on operation histories (63\%) patients that hadn't experience the operation yet, and based on the information resources $(53,3 \%)$ patients who had known the operation procedure.

Conclusion. Most of the patients don't feel anxiety (51,8\%) and for the information, the most needed was low information $(48,2 \%)$.

Keywords. Anxiety, pre-operative anxiety, cesarean section, spinal anesthesia.

\section{Apa yang sudah diketahui tentang topik ini?}

Operasi merupakan salah satu penyebab tersering pasien mengalami kecemasan preoperatif di dunia.

\section{Apa yang ditambahkan pada studi ini?}

Hasil dari penelitian menggunakan kuesioner The Amsterdam Preoperative Anxiety and Information Scale (APAIS) menunjukkan bahwa sebagian besar pasien tidakk mengalami kecemasan dan untuk kebutuhan informasi lebih banyak pada kebutuhan informasi rendah.

CORRESPONDING AUTHOR

Name: Rani Ilma Imani

Phone: +6282383525242

E-mail: raniilmaimani@yahoo.com

ARTICLE INFORMATION

Received: September $23^{\text {rd }}$, 2020

Revised: October $15^{\text {th }}, 2020$

Available online: October $31^{\text {st }}, 2020$ 


\section{Pendahuluan}

Kecemasan adalah respons terhadap suatu ancaman yang asalnya tidak diketahui, internal, samar-samar, atau konfliktual. ${ }^{1}$ Salah satu hal yang paling sering menyebabkan kecemasan ketika pasien dinyatakan akan menjalani operasi. ${ }^{2}$ Penyebab kecemasan preoperatif diakibatkan oleh rasa takut terhadap prosedur operasi dan anestesi yang dapat menyebabkan rasa nyeri saat proses operasi berlangsung dan sesudah operasi.3,4 Penyebab kecemasan preoperatif dipengaruhi oleh beberapa faktor risiko seperti usia, jenis kelamin, status pendidikan, riwayat operasi sebelumnya, dan status medis. ${ }^{5}$

Pasien dengan tingkat kecemasan preoperatif yang tinggi memerlukan dosis anestesi yang lebih banyak, baik sebelum operasi maupun sesudah operasi. Kecemasan juga berdampak pada lamanya rawatan di rumah sakit dan meningkatnya angka kesakitan dan kematian. Masalah tersebut menjelaskan bahwa pasien dengan kecemasan preoperatif perlu dinilai dan ditangani dengan baik. ${ }^{6}$

Insiden kecemasan preoperatif didapatkan dari beberapa penelitian di dunia memiliki hasil yang sangat bervariasi, yaitu antara $11 \%$ hingga $80 \%{ }^{6}$ Hasil penelitian di rumah sakit Pakistan pada tahun 2009 didapatkan 62\% pasien mengalami kecemasan preoperatif. Faktor yang berpengaruh seperti jenis kelamin perempuan, usia, dan pasien dengan tingkat pendidikan yang tinggi. 7,8 Penelitian di India menyebutkan bahwa operasi obstetri dan ginekologi merupakan operasi yang paling sering dilakukan dengan $32,4 \%$ dari seluruh jenis operasi yang ada dengan tindakan Sectio Caesarea (SC) sekitar 3,32\%. ${ }^{9}$ Di Indonesia dari hasil penelitian di Kabupaten Mojokerto, Jawa Timur didapatkan $63 \%$ pasien mengalami kecemasan preoperatif. Faktor yang berpengaruh adalah dukungan suami, komplikasi pasca persalinan, usia, paritas, dan jenis SC. 10

Operasi SC merupakan proses melahirkan janin dengan insisi pada bagian dinding perut (laparotomi) dan insisi pada bagian dinding uterus (histerektomi). ${ }^{11}$ Operasi SC merupakan upaya yang dilakukan untuk menolong masalah kehamilan, namun di satu sisi operasi SC memiliki beberapa bahaya komplikasi. Nyeri pasca operasi merupakan salah satu akibat yang ditimbulkan oleh kecemasan preoperatif. ${ }^{12}$
Hasil penelitian tindakan SC dengan anestesi regional dapat menekan angka kematian ibu (AKI). ${ }^{13}$ Anestesi regional terdiri dari anestei spinal, anestesi epidural, dan combined spinal epidural (CSE). Teknik anestesi spinal lebih banyak dipilih karena onsetnya yang cepat dan tingkat kegagalannya rendah, namun anestesi spinal juga dapat mengakibatkan penurunan tekanan darah dan dapat menimbulkan efek samping yang berbahaya bagi ibu dan janin.14,15 Penelitian ini ditunjukkan untuk melihat gambaran kecemasan pasien preoperatif dengan anestesi spinal di RSIA Siti Hawa Padang.

\section{Metode}

Jenis penelitian ini adalah deskriptif observasional dengan desain cross sectional. Penelitian ini dilakukan dengan cara mewawancarai secara langsung pasien yang akan menjalani operasi SC di RSIA Siti Hawa Padang. Populasi penelitian yaitu semua pasien yang akan melakukan operasi SC dengan anestesi spinal di RSIA Siti Hawa Padang periode Juli 2018 Agustus 2018. Jumlah sampel penelitian sebanyak 83 orang sesuai dengan kriteria inklusi dan ekslusi.

Kriteria inklusi adalah pasien yang akan menjalankan operasi SC dengan anestesi spinal, pasien dengan status fisik ASA I dan II, dan pasien bersedia menjadi subjek penelitian. Kriteria ekslusi adalah pasien yang pernah mengalami gangguan kecemasan sebelumnya dan memiliki riwayat berobat ke psikiater dan pasien yang tidak dapat menyelesaikan pengerjaan kuesioner.

Teknik pengambilan sampel adalah consecutive sampling. Data disajikan dengan mendistribusikan melalui analisis univariat. Analisis univariat dilakukan terhadap tiap variabel dari hasil penelitian. Tujuan dari analisis ini untuk menghasilkan distribusi dan persentase dari tiap variabel.

Hasil

Penelitian ini dilakukan secara deskriptif tentang gambaran kecemasan pasien preoperatif SC dengan anestesi spinal di RSIA Siti Hawa Padang Periode Juli - Agustus 2018 dengan rincian 83 pasien sesuai dengan kriteria inklusi dan ekslusi. 
Tabel 1. Distribusi Karakteristik Responden Penelitian

\begin{tabular}{lcc}
\hline $\begin{array}{c}\text { Karakteristik } \\
\text { Responden }\end{array}$ & $\begin{array}{c}\text { Frekuensi } \\
\text { (f) }\end{array}$ & $\begin{array}{c}\text { Persentase } \\
\text { (\%) }\end{array}$ \\
\hline Usia (Tahun) & & \\
$<20$ & 0 & 0 \\
$20-35$ & 63 & 75,9 \\
$>35$ & 20 & 24,1 \\
Tingkat Pendidikan & & \\
SD & 0 & 0 \\
SMP & 7 & 8,4 \\
SMA & 41 & 49,4 \\
Perguruan Tinggi & 35 & 42,2 \\
Riwayat Operasi & & \\
Belum Pernah & 27 & 32,5 \\
Pernah & 56 & 67,5 \\
Sumber Informasi & & \\
Ada & 30 & 36,1 \\
Tidak Ada & 53 & 63,9 \\
\hline
\end{tabular}

Berdasarkan tabel 1 diketahui pasien yang akan menjalankan operasi SC dengan anestesi spinal di RSIA Siti Hawa Padang terbanyak pada usia 20 sampai 35 tahun yang berjumlah 63 orang (75,9\%). Berdasarkan tingkat pendidikan terbanyak pada pasien lulusan SMA dengan 41 orang $(49,4 \%)$. Berdasarkan riwayat operasi terbanyak pada pasien yang sudah pernah menjadi operasi sebelumnya 56 orang $(67,5 \%)$. Dan berdasarkan sumber informasi terbanyak pada pasien yang tidak mengetahui tentang prosedur operasi SC 53 orang $(63,9 \%)$.

Tabel 2. Kecemasan Preoperatif Responden Penelitian (APAIS)

\begin{tabular}{lcc}
\hline $\begin{array}{c}\text { Kecemasan } \\
\text { Preoperatif }\end{array}$ & $\begin{array}{c}\text { Frekuensi } \\
\text { (f) }\end{array}$ & $\begin{array}{c}\text { Persentase } \\
\text { (\%) }\end{array}$ \\
\hline Cemas & 40 & 48,2 \\
Tidak Cemas & 43 & 51,8 \\
\hline
\end{tabular}

Berdasarkan tabel 2 kecemasan preoperatif ini yang diukur dengan menggunakan kuesioner APAIS. Hasilnya menunjukkan lebih banyak pasien yang tidak mengalami kecemasan 43 orang (51,8\%) dibandingkan dengan pasien yang mengalami kecemasan 40 orang $(48,2 \%)$.

Tabel 3. Tingkat Kebutuhan Informasi Responden Penelitian (APAIS)

\begin{tabular}{lcc}
\hline $\begin{array}{c}\text { Tingkat Kebutuhan } \\
\text { Informasi }\end{array}$ & $\begin{array}{c}\text { Frekuensi } \\
\text { (f) }\end{array}$ & $\begin{array}{c}\text { Persentase } \\
\text { (\%) }\end{array}$ \\
\hline Rendah/Tidak ada & 40 & 48,2 \\
Sedang & 25 & 30,1 \\
Tinggi & 18 & 21,7 \\
\hline
\end{tabular}

Berdasarkan tabel 3 kuesioner APAIS selain bisa digunakan untuk mengukur kecemasan preoperatif, kuesioner ini juga dapat digunakan untuk mengukur tingkat kebutuhan informasi pasien. Hasilnya kebutuhan informasi terbanyak adalah kebutuhan informasi rendah 40 orang $(48,2 \%)$.

Tabel 4. Kecemasan Preoperatif Berdasarkan Karakteristik (APAIS)

\begin{tabular}{lcccc}
\hline \multicolumn{1}{c}{ Karakteristik } & \multicolumn{2}{c}{ Cemas } & \multicolumn{2}{c}{ Tidak } \\
& \multicolumn{3}{c}{ Cemas } \\
\cline { 2 - 5 } & f & $\mathbf{\%}$ & f & $\mathbf{\%}$ \\
\hline $\begin{array}{l}\text { Usia (Tahun) } \\
\quad 20\end{array}$ & 0 & 0 & 0 & 0 \\
$\quad 20-35$ & 34 & 54 & 29 & 46 \\
$\quad>35$ & 6 & 30 & 14 & 70 \\
Tingkat Pendidikan & & & & \\
$\quad$ SD & 0 & 0 & 0 & 0 \\
$\quad$ SMP & 0 & 0 & 7 & 100 \\
$\quad$ SMA & 17 & 41,5 & 24 & 58,5 \\
$\quad$ Perguruan Tinggi & 22 & 62,9 & 13 & 37,1 \\
Riwayat Operasi & & & & \\
$\quad$ Belum Pernah & 17 & 63 & 10 & 37 \\
$\quad$ Pernah & 23 & 41,1 & 33 & 58,9 \\
Sumber Informasi & & & & \\
$\quad$ Ada & 16 & 53,3 & 14 & 46,7 \\
$\quad$ Tidak ada & 25 & 47,2 & 28 & 52,8 \\
\hline
\end{tabular}

Berdasarkan tabel 4 menunjukkan bahwa kelompok usia 20 sampai 35 tahun mengalami kecemasan terbanyak dengan 34 orang (54\%). Pada pasien dengan lulusan perguruan tinggi memiliki kecemasan preoperatif terbanyak yaitu 22 orang $(62,9 \%)$, sedangkan pasien dengan kecemasan preoperatif lebih banyak pada pasien yang belum pernah menjalani operasi sebelumnya. Selain itu, sumber informasi pasien yang telah mendapatkan informasi seputar prosedur operasi SC lebih cemas dengan 16 orang $(53,3 \%)$.

Tabel 5. Tingkat Kebutuhan Informasi Berdasarkan Karakteristik (APAIS)

\begin{tabular}{lcccccc}
\hline Karakteristik & \multicolumn{2}{c}{$\begin{array}{c}\text { Kebutuhan } \\
\text { Informasi } \\
\text { Rendah }\end{array}$} & $\begin{array}{c}\text { Kebutuhan } \\
\text { Informasi } \\
\text { Sedang }\end{array}$ & \multicolumn{2}{c}{$\begin{array}{c}\text { Kebutuhan } \\
\text { Informasi } \\
\text { Tinggi }\end{array}$} \\
\cline { 2 - 8 } & $\mathbf{f}$ & $\mathbf{\%}$ & $\mathbf{f}$ & $\mathbf{\%}$ & $\mathbf{f}$ & $\mathbf{\%}$ \\
\hline Usia (Tahun) & & & & & & \\
$\quad<20$ & 0 & 0 & 0 & 0 & 0 & 0 \\
$20-35$ & 24 & 38,1 & 23 & 36,5 & 16 & 25,4 \\
$>35$ & 16 & 80 & 2 & 10 & 2 & 10 \\
Tingkat & & & & & & \\
Pendidikan & & & & & & \\
$\quad$ SD & 0 & 0 & 0 & 0 & 0 & 0 \\
SMP & 6 & 85,7 & 1 & 14,3 & 0 & 0 \\
$\quad$ SMA & 25 & 61 & 11 & 26,8 & 5 & 12,2 \\
$\quad$ Perguruan Tinggi & 9 & 25,8 & 13 & 37,1 & 13 & 37,1 \\
Riwayat Operasi & & & & & & \\
$\quad$ Belum Pernah & 6 & 22,2 & 14 & 51,9 & 7 & 25,9 \\
$\quad$ Pernah & 34 & 60,8 & 11 & 19,6 & 11 & 19,6 \\
Sumber Informasi & & & & & & \\
$\quad$ Ada & 13 & 43,3 & 8 & 26,7 & 9 & 30 \\
$\quad$ Tidak ada & 27 & 50,9 & 16 & 30,2 & 10 & 18,9 \\
\hline
\end{tabular}


Berdasarkan tabel 5 pasien dengan usia 20 sampai 35 tahun dan usia diatas 35 tahun lebih banyak pada kebutuhan informasi rendah yaitu 24 orang $(38,1 \%)$ dan 16 orang (80\%). Pada lulusan SMP dan SMA lebih banyak pada kebutuhan informasi rendah yaitu 6 orang $(85,7 \%)$ dan 25 orang (61\%). Lulusan perguruan tinggi terbanyak pada kebutuhan informasi sedang dan kebutuhan informasi tinggi yaitu 13 orang $(37,1 \%)$. Selain itu, terdapat perbedaan kebutuhan informasi pada riwayat operasi. Pasien yang belum pernah menjalani operasi lebih banyak kebutuhan informasi sedang 14 orang $(51,9 \%)$. Pasien yang sudah pernah menjalani operasi lebih banyak pada kebutuhan informasi rendah 34 orang (60,8\%). Berdasarkan sumber informasi lebih banyak pada kebutuhan informasi rendah baik pasien yang sudah pernah mendapat informasi seputar operasi maupun yang tidak pernah mendapatkan informasi yaitu 13 orang $(43,3 \%)$ dan 27 orang (50,9\%).

\section{Pembahasan}

Berdasarkan penelitian yang dilakukan pada pasien yang akan menjalani operasi SC dengan anestesi spinal di RSIA Siti Hawa Padang periode Juli sampai Agustus 2018 sesuai hasil tabel 1 diperoleh pasien dengan kelompok usia 20 sampai 35 tahun lebih banyak yaitu 63 orang $(75,9 \%)$. Hasil ini sejalan dengan penelitian yang dilakukan di Nigeria dari 224 pasien yang menjalani operasi SC, pasien dengan rentang usia 26 sampai 30 tahun menjadi pasien terbanyak yang menjalani operasi SC $(43,8 \%)$ dan diikuti dengan rentang usia 31 sampai 35 tahun (33,0\%). Penelitian di Pakistan juga menyebutkan bahwa operasi SC terbanyak pada rentang usia 26 sampai 35 tahun. ${ }^{16,17}$ Menurut teori usia 20 sampai 35 tahun merupakan kategori usia ideal dalam kesehatan produksi untuk hamil maupun melahirkan. ${ }^{18}$

Pasien dengan lulusan SMA (49,4\%) menjadi pasien terbanyak. Hal ini kemungkinan didapatkan berdasarkan hasil Badan Pusat Statistik (BPS) Provinsi Sumatera Barat tahun 2016 yang mana lulusan SMA menjadi lulusan terbanyak dengan (30,03\%). ${ }^{19}$ Sebagian besar pasien sudah pernah menjalani operasi $(67,5 \%)$. Hasil survei demografi dan kesehatan Indonesia (SKDI) tahun 2012 juga menunjukkan bahwa adanya kenaikan operasi SC dari tahun 2007 (7\%) menjadi (12\%) pada tahun 2012.20
Berdasarkan sumber informasi lebih banyak pasien yang tidak pernah mendapatkan informasi seputar operasi SC $(63,9 \%)$. Hasil ini sesuai dengan penelitian di Iran mengenai sedikitnya informasi ibu hamil mengenai prosedur operasi SC. Hal ini terjadi karena pasien menyerahkan semua keputusan yang ada kepada dokter tanpa mencari informasi lebih lanjut. ${ }^{21}$

Berdasarkan hasil penelitian menggunakan kuesioner APAIS pada tabel 2 lebih banyak pasien yang tidak mengalami kecemasan preoperatif (51,8\%). Sedangkan, penelitian di Kabupaten Mojokerto, Jawa Timur (63\%) pasien mengalami kecemasan preoperatif. ${ }^{10}$ Terdapat beberapa hal yang dapat membuat perbedaan hasil kecemasan yaitu perbedaan pendekatan penelitian, alat pengukuran, dan populasi yang diteliti. ${ }^{22}$

Kuesioner APAIS selain menilai kecemasan pasien berdasarkan prosedur operasi dan prosedur anestesi juga dapat digunakan untuk menilai tingkat kebutuhan informasi pasien. Pada tabel 3 hasilnya lebih banyak tingkat kebutuhan informasi rendah (48,2\%), diikuti kebutuhan informasi sedang $(30,1 \%)$, dan kebutuhan informasi tinggi $(21,7 \%)$. Hasil ini sejalan dengan penelitian di Sri Lanka bahwa kebutuhan informasi sejalan dengan hasil kecemasan preoperatif pasien. ${ }^{3}$

Berdasarkan usia pasien yang mengalami kecemasan preoperatif pada tabel 4 lebih banyak pada usia 20 sampai 35 tahun (54\%), diikuti pasien usia diatas 35 tahun (30\%), dan pasien usia dibawah 20 tahun tidak ada (0\%) karena tidak terdapatnya sampel usia dibawah 20 tahun. Hasil penelitian ini sesuai dengan penelitian di Pakistan bahwa pasien usia dibawah 25 tahun menjadi pasien dengan kecemasan preoperatif terbanyak $(84,8 \%)$. Menurut teori pasien usia lebih muda akan cenderung lebih cemas dibandingkan pasien yang lebih tua. Maturitas menjadi alasan kenapa pasien dengan usia lebih muda cenderung lebih cemas. ${ }^{23}$

Berdasarkan tingkat pendidikan pada tabel 4 semakin tinggi jenjang pendidikan maka pasien akan semakin cemas. Pasien dengan kecemasan preoperatif yang paling banyak pada lulusan perguruan tinggi $(62,9 \%)$ dan diikuti lulusan SMA $(41,5 \%)$. Hasil ini sesuai dengan penelitian di Pakistan yang mana menunjukkan bahwa tingkat pendidikan dapat mempengaruhi kecemasan preoperatif pasien. Hasil ini terjadi karena pasien 
mengerti bagaimana menginterpretasikan perasaannya sesuai dengan apa yang dirasakan dan pasien cenderung untuk mencari informasi sendiri sehingga informasi yang didapat cenderung tidak lengkap dan menyebabkan kesalahpahaman persepsi. Hal ini dapat meningkatkan kecemasan pada pasien dengan tingkat pendidikan yang tinggi. ${ }^{7}$

Berdasarkan hasil pada tabel 4 pasien yang belum pernah menjalani operasi (63\%) cenderung lebih cemas dibandingkan yang sudah pernah menjalani operasi $(41,1 \%)$. Hal ini sesuai dengan penelitian di Pakistan pasien yang memiliki riwayat operasi sebelumnya kecemasannya cenderung lebih rendah dibanding pasien yang pertama kali melakukan operasi. Hal ini terjadi karena pasien dianggap sudah mampu beradaptasi atas keadaan yang sama. ${ }^{25}$

Berdasarkan sumber informasi pada tabel 4 menunjukkan bahwa kecemasan preoperatif lebih banyak pada pasien yang telah mendapatkan informasi seputar prosedur operasi SC (53,3\%) dibandingkan pasien yang tidak memiliki pengetahuan seputar operasi SC $(47,2 \%)$ Hasil ini sejalan dengan penelitian di Pakistan pasien yang mendapatkan sumber informasi yang tidak sesuai atau bukan dari ahlinya pasien akan cenderung lebih cemas $(89,7 \%){ }^{23}$

Hasil dari tingkat kebutuhan informasi berdasarkan usia pada tabel 5 lebih banyak pada kebutuhan informasi rendah. Usia 20 sampai 35 tahun terbanyak pada kebutuhan informasi rendah $(38,1 \%)$, diikuti kebutuhan informasi sedang $(36,5 \%)$, dan kebutuhan informasi tinggi $(25,4 \%)$. Usia diatas 35 tahun kebutuhan informasi rendah (80\%) dan diikuti kebutuhan informasi sedang maupun kebutuhan informasi tinggi sama-sama (10\%). Pada usia diatas 35 tahun hasilnya tingkat kebutuhan informasi akan sejalan dengan kecemasan. Pasien usia 20 sampai 35 tahun lebih banyak pada kebutuhan informasi rendah. Namun, tidak terdapat perbedaan yang terlalu signifikan dengan kebutuhan informasi sedang dan tinggi sehingga hasil ini harus tetap disesuaikan berdasarkan hasil kecemasan pasien. ${ }^{22}$

Berdasarkan tingkat pendidikan pada tabel 5 tentang tingkat kebutuhan informasi juga sesuai dengan hasil kecemasan pasien. Pasien dengan tingkat pendidikan rendah sebagian besar memiliki kebutuhan informasi rendah. Lulusan
SMP kebutuhan informasi rendah $(85,7 \%)$, diikuti kebutuhan informasi sedang (14,3\%), dan kebutuhan informasi tinggi yang sama sekali tidak ada. Lulusan SMA kebutuhan informasi rendah (61\%), diikuti kebutuhan informasi sedang $(37,1 \%)$, dan terakhir kebutuhan informasi tinggi $(12,2 \%)$. Hasil ini berbeda dengan lulusan perguruan tinggi kebutuhan informasi paling banyak adalah kebutuhan informasi tinggi dan sedang yang sama-sama $(37,1 \%)$ dan diikuti kebutuhan informasi rendah $(25,8 \%)$. Hal ini sejalan dengan penelitian di Jerman bahwa tingkat pendidikan dapat mempengaruhi kebutuhan informasi pasien. Oleh karena itu, pemberian informasi terhadap pasien harus sesuai dengan apa yang dibutuhkan pasien. ${ }^{24}$

Berdasarkan riwayat operasi pada tabel 5 menunjukkan bahwa pasien yang belum pernah menjalani operasi lebih banyak pada tingkat kebutuhan informasi sedang $(51,9 \%)$, diikuti kebutuhan informasi tinggi (25,9\%), dan kebutuhan informasi rendah (22,2\%). Pasien yang sudah pernah menjalani operasi lebih banyak pada kebutuhan informasi rendah $(60,8 \%)$ dan diikuti kebutuhan informasi sedang dan kebutuhan informasi tinggi yang nilainya samasama $(19,6 \%)$. Hasil ini sesuai dengan penelitian terhadap karakteristik kuesioner APAIS. Riwayat operasi sebelumnya dapat mempengaruhi tingkat kebutuhan informasi yang diinginkan pasien. ${ }^{22}$

Berdasarkan sumber informasi pada tabel 5 menunjukkan tingkat kebutuhan informasi terbanyak adalah kebutuhan informasi rendah. Pasien yang mendapat informasi seputar prosedur operasi SC kebutuhan informasi rendahnya sebanyak $(43,3 \%)$, diikuti kebutuhan informasi tinggi (30\%), dan kebutuhan informasi sedang $(26,7 \%)$. Pasien yang tidak mengetahui prosedur operasi kebutuhan informasi rendahnya sebanyak $(52,8 \%)$, diikuti kebutuhan informasi sedang $(28,3 \%)$, dan kebutuhan informasi tinggi $(18,7 \%)$. Hasil ini sesuai dengan karakteristik kuesioner APAIS bahwa pasien yang lebih cemas cenderung menginginkan lebih banyak informasi terkait dengan keadaannya sekarang. ${ }^{22}$

\section{Simpulan}

Berdasarkan hasil penelitian ini dapat disimpulkan bahwa sebagian besar pasien tidak mengalami kecemasan preoperatif $(51,8 \%)$ dan dengan lebih banyak pada tingkat kebutuhan 
informasi rendah (48,2\%). Kelompok usia 20 sampai 35 tahun merupakan kelompok usia terbanyak yang mengalami kecemasan preoperatif (54\%). Pasien lulusan perguruan tinggi merupakan pasien terbanyak yang mengalami kecemasan preoperatif (62,9\%). Pasien yang belum pernah menjalani operasi merupakan pasien terbanyak yang mengalami kecemasan preoperatif (63\%). Pasien yang telah mendapatkan informasi seputar prosedur operasi SC merupakan pasien terbanyak yang mengalami kecemasan preoperatif $(53,3 \%)$.

\section{Ucapan Terima Kasih}

Ucapan terima kasih peneliti ditujukan kepada seluruh pihak yang turut membantu dalam menyelesaikan penelitian ini.

\section{Daftar Pustaka}

1. Kaplan HI, Saddock BJ, Grebb JA. Sinopsis Psikiatri, Jilid 2. Kusuma W, penerjemah. Tangerang: Binarupa Aksara Publisher;2010.18 p.

2. Nigussie S, Belachew T, Wolancho W. Predictors of preoperative anxiety among surgical patients in Jimma University Specialized Teaching Hospital, South-Western Ethiopia. BMC Surg. 2014;14(1):67.

3. Matthias AT, Samarasekera DN. Preoperative anxiety in surgical patients - Experience of a single unit. Acta Anaesthesiol Taiwanica. 2012;50(1):3-6.

4. Tulgar S, Boga I, Piroglu MD, Ates NG, Bombaci E, Can $\mathrm{T}$, et al. Preoperative Anxiety before Spinal Anesthesia: Does Internet-based Visual Information/Multimedia Research Decrease Anxiety and Information Desire? A Prospective Multicentered Study. Anesth Essays Res. 2017 Apr-Jun; 11(2): 390396.

5. Caumo W, Schmidt AP, Schneider CN, Bermann J, Iwamoto CW, Bandeira D, et al. Risk factors for preoperative anxiety in adults. Acta Anaesthesiol Scand. 2001;(12):298-307.

6. Romero MV, Asencio JMM, Fernandez AM, Sanchez JCC, Ruiz FR, Lapuerta AR. Validation of the Spanish version of the Amsterdam Preoperative Anxiety and Information Scale (APAIS). Health and Quality of Life Outcomes (2017) 15:120.

7. Jafar MF, Khan FA. Frequency of preoperative anxiety in Pakistani surgical patients. J Pak Med Assoc. 2009;59(6):359-63.

8. Maideen SFK, Sidik SM, Rampal L, Mukhtar F. Prevalence, associated factors, and predictors of anxiety: A community survey in Selangor, Malaysia. BMC Psychiatry. 2015;15(1):1-12.

9. Bhasin SK, Roy R, Agrawal S, Sharma R. An Epidemiological Study of Major Surgical Procedures in an Urban Population of East Delhi. Indian J Surg. 2011;73(2):131-5.

10. Irawati D. Faktor-faktor yang mempengaruhi kecemasan ibu menghadapi persalinan Sectio Caesarea (SC) di RSUD R.A. Basoeni Kab. Mojokerto. J Ners dan Kebidanan (Journal Ners Midwifery). 2017;3(3):310.
11. Cunningham FG, Leveno KJ, Bloom SL, Spong CY, Dashe JS, Hoffman BL, et al. Obstetric Williams. Edisi 23. Pendit BU, penerjemah, Jakarta: EGC; 2012. 568 p.

12. Stephens J. The burden of acute postoperative pain and the potential role of the COX-2-specific inhibitors. Rheumatology. 2003;42(90003):40iii-52.

13. Paez JJ, Navarro JR. Regional Versus General Anesthesia for Caesarean Section Delivery. Rev colomb Anaesthesiol. 2012;40(3):203-206.

14. Amin SE. Evaluation of the Minimal Effective Dose of Levobubivacaine and Bubivacaine in Caesarean Section Under Spinal Anaesthesia. (Thesis). Al Qalyubiyah: Benha Faculty of Medicine; 2015.

15. Prihyanto. Pengaruh Pemberian Informed Consent Terhadap Kecemasan Preoperasi Sectio Caesarea dengan Anestesi Spinal di RSUD RAA Soewondo Pati. (Tesis). Surakarta: Universitas Sebelas Maret; 2012.

16. Chukwu EO, Ekeh CJ, Haruna H, Chia T, Fiase TM. Prevalence of Caesarean Section Deliveries Among Primigravidae in General Hospital Gboko, Benue State, Nigeria. International Journal of Clinical and Experimental Medical Sciences. Vol. 3, No. 5, 2017, pp. 61-65.

17. Ishaq $R$, Baloch NS, Iqbal Q, Saleem F, Hassali MA, Iqbal J, et al. Frequency and evaluation of the perceptions towards cesarean section among pregnant women attending public hospitals in Pakistan and the implications. Hosp Pract (1995). 2017;45(3):104-10.

18. Saifuddin $A B$, Rachimhadhi $T$, Wiknjosastro $G H$, editors. Ilmu Kebidanan. Jakarta: PT Bina Pustaka Sarwono prawirohardjo; 2010.

19. Febriyanti D, editors. Profil Pendidikan Provinsi Sumatera Barat 2016. Padang: Badan Pusat Statistik Provinsi Sumatera Barat; 2017. Diakses Januari 2018.

20. Badan Kependudukan dan Keluarga Berencana Nasional. (2013) Survei Demografi dan Kesehatan Indonesia 2012 http://chnrl.org/pelatihandemografi/SDKI-2012.pdf. Diakses Januari 2018.

21. Ghotbi F, Sene AA, Azargashb E, Shiva F, Mohtadi M, Zadehmodares S, et al. Women's knowledge and attitude towards the mode of delivery and frequency of cesarean section on mother's request in six public and private hospitals in Tehran, Iran, 2012. J Obstet Gynaecol Res. 2014;40(5):1257-66.

22. Moerman N, van Dam FS, Muller MJ, Oosting H. The Amsterdam preoperative anxiety and information scale (APAIS). Anesthesia \& Analgesia. 1996;82:446.

23. Woldegerima YB, Fitwi GL, Yimer HT, Hailekiros AG. Prevalence and factors associated with preoperative anxiety among elective surgical patients at the University of Gondar Hospital. Gondar, Northwest Ethiopia, 2017. A cross-sectional study. Int J Surg Open. 2018;10:21-9.

24. Aust $H$, Rüsch D, Schuster $M$, Sturm T, Brehm F, Nestoriuc Y. Coping strategies in anxious surgical patients. BMC Health Serv Res. 2016;1-10.

25. Jawaid M, Mushtaq A, Mukhtar S, Khan Z. Preoperative anxiety before elective surgery. Neurosciences 2007; 12(2): 145-8. 